\title{
Questionnaire survey for the clinical trial participants who experienced both digital and conventional impression
}

\author{
Eunbee Yang', Bongju Kim², Jun Jae Lee 1 , Seung-Pyo Lee ${ }^{3}$, Young-Jun Lim* \\ 'Department of Prosthodontics and Dental Research Institute, School of Dentistry, Seoul National University, Seoul, Republic \\ of Korea \\ ${ }^{2}$ Dental Life Science Research Institute \& Clinical Translational Research Center for Dental Science, Seoul National University \\ Dental Hospital, Seoul, Republic of Korea \\ ${ }^{3}$ Department of Oral Anatomy, School of Dentistry, Seoul National University, Seoul, Republic of Korea
}

Purpose: The aim of this study was to assess the patients' perception, acceptance, and preference of the difference between a conventional impression and digital impression through questionnaire survey. Materials and Methods: Thirteen (6 male, 7 female) subjects who experienced both digital and conventional impression at the same day were enrolled in this study. Conventional impression were taken with polyvinylsiloxane and digital impression were performed using a newly developed intra-oral scanner. Immediately after the two impressions were made, a survey was conducted with the standardized questionnaires consisting of the following three categories; 1) general dental treatment 2) satisfaction of conventional impression 3) satisfaction of digital impression. The perceived source of satisfaction was evaluated using Likert scale. The distribution of the answers was assessed by percentages and statistical analyses were performed with the paired t-test, and $P<0.05$ was considered significant. Results: There were significant differences of the overall satisfaction between two impression methods $(P<0.05)$. Digital impression showed high satisfaction in less shortness of breath and odor to participants compared to conventional impression. The use of an oral scanner resulted in a discomfort of TMJ due to prolonged mouth opening and in lower score of the scanner tip size. Conclusion: It was confirmed that the preference for the digital impression using intraoral scanner is higher than the conventional impression. Most survey participants said they would recommend the digital impression to others and said they preferred it for future prosthetic treatment. (J Dent Rehabil Appl Sci 2018;34(4):270-9)

Key words: questionnaire survey; conventional impression; digital impression; intraoral scanner; clinical trial

\footnotetext{
서론

시대의 변화와 기술의 발전은 치과영역의 치과보철물 제작 시스템 변화에도 영향을 주었다. 최근까지 치과보 철물의 제작은 아날로그 방식인 인상채득 작업을 통해 획득한 인상체를 경석고로 주모형을 완성하고, 기공사의 수작업에 의존하여 보철물을 제작하였다. 여러 과정을

*Correspondence to: Young-Jun Lim

Professor, Department of Prosthodontics and Dental Research Institute, School of Dentistry, Seoul National University, 101, Daehak-ro, Jongno-gu, Seoul, 03080, Republic of Korea

Tel: +82-2-2072-2940, Fax: +82-2-2072-3860, E-mail: limdds@snu.ac.kr

Received: August 17, 2018/Last Revision: September 12, 2018/Accepted:

October 2, 2018
}

거쳐서 수작업에 의존한 보철물 제작방식은 기공과정에 서 필연적으로 발생하는 오차 및 기공사 개인의 기술수 준에 따라 차이가 나타나게 되는 문제점이 수반된다. ${ }^{1,2}$

이러한 단점은 최근 대두되고 있는 디지털 $\mathrm{CAD} /$ CAM (Computer-aided design/Computer-aided manufacture) 시스템에 의하여 보완될 수 있다., ${ }^{3,4}$ 이러한 시스 템을 구현하여 대중화하기 위해서는 구강스캐너를 사용

Copyright(C) 2018 The Korean Academy of Stomatognathic Function and Occlusion. (c) It is identical to Creative Commons Non-Commercial License. 
하여 얻은 디지털인상의 정확도(accuracy)가 필수적인 요 소라고 할 수 있다. ${ }^{5}$ 종래형인상법과 달리 구강스캐너를 이용한 디지털인상은 치과 진료의 임상과정 및 기공과정 의 단순화로 발생하는 오차를 피할 수 있고, 진료시간 및 작업시간을 획기적으로 단축할 후 있으며, 비용과 효율 성 측면에서도 이점이 있기 때문에 점차 그 중요성이 커 지고 있다. ${ }^{6,7}$ 또한 실제 획득한 인상체를 인력을 이용하 여 기공소로 배송할 필요가 없으며, 온라인상으로 기공 사와 치아삭제 상태와 보철물 디자인을 동시에 체크하고 향후 작업 과정에 대해 논의하는 것도 가능하다.

디지털 인상에 사용되는 구강 스캐너는 외국 회사에서 제작된 제품들밖에 없어서 선택에 제한이 있었는데, 최근 에 국내 회사에서도 구강 스캐너가 개발되어 시판을 앞 두고 있다.

본 연구는 “새로 개발된 국산 구강 스캐너와 간접법 디 지털 인상의 정확도 및 $\mathrm{CAD} / \mathrm{CAM}$ 으로 제작된 단일구 조 지르코니아 단일금관의 적합도 평가 임상연구” 라는 제목으로 서울대학교 치과병원에서 진행되고 있는 임상 시험의 일부이다. 이 임상시험은 국내에서 새롭게 개발된 구강 스캐너의 임상적용 시 유용성을 평가하기 위해, 폴 리비닐실록산 인상재를 사용한 종래형 인상법으로 제작 한 수복물과 국내 개발된 구강스캐너를 사용하여 제작 한 수복물의 정확도를 비교하여 임상에서의 효용성을 평 가하였다.

이 연구의 목적은 임상시험과 관련하여 종래형인상과 디지털인상을 당일에 경험한 13 명의 임상시험참여자를 대상으로 느낌, 만족도와 선호도에 대한 설문조사내용을 분석하는 것이다. 귀무가설은 "당일에 디지털인상과 종 래형인상을 경험한 환자의 설문조사결과 선호도나 만족 도에 차이가 없다"는 것이다

\section{연구 재료 및 방법}

\section{1. 연구대상}

이 연구는 서울대학교 치과병원에서 2017년 12월 7 일에 시작하여 2018년 8월 22일에 종료된 “새로 개발 된 국산 구강 스캐너와 간접법 디지털 인상의 정확도 및 $\mathrm{CAD} / \mathrm{CAM}$ 으로 제작된 단일구조 지르코니아 단일금관 의 적합도 평가 임상연구”에 참여한 13명의 임상시험자 를 대상으로 설문이 진행되었다.

목표연구대상자 수는 paired t-test에 의한 우위성 비교
평가(환자 한 사람에 대한 금관제작방식이 디지털인상제 작 + 종래형 인상제작)를 위한 수식을 이용하였으며 (제 1 종 오류는 $5 \%$, 제 2 종 오류는 $20 \%$, 피검자에 의한 예상 탈락률은 $10 \%$, 임상평가에서 발생할 수 있는 에러(탈락 시킴)는 $10 \%$ 로 설정), 기존에 발표한 논문(Zhang F, et al. 2016)의 결과를 바탕으로 활용 가능한 연구지원비와 필요한 적정 수를 고려하여 13 명으로 최종 산출하였다. ${ }^{8}$

본 연구에 참여에 자발적으로 동의한 만 19세 이상 70 세 미만으로 악골의 성장이 완료된 성인 환자를 대상으 로 하였으며, 시험대상자의 선정은 단일금관 수복이 필 요한 치아가 치과보철물 제작을 위한 지대치의 조건(다 른 추가적인 치료가 필요하지 않고, 치관/치근 비, 치주 적으로 건강, 근원심 및 협설로 기울어 있지 않고, 정출되 지 않은 경우 등)을 만족하는 자로 하였으며, 치과보철치 료에 일반적인 금기증을 가진 대상자는 제외되었다.

연구대상자는 서울시 지하철 광고를 통하여 모집하 였고, 연구 계획은 서울대학교 치과병원 Institutional Review Board (IRB No. CDE17004)의 승인을 받았다. 모든 연구 대상자는 시술에 대한 정보를 인지하고, 동의서에 서명 하였다.

\section{2. 연구방법}

설문을 진행한 임상시험의 내용은 다음과 같다.

상-하악 제 1 소구치, 제 2 소구치 또는 제 1 대구치에 단 일금관 수복이 필요한 환자를 대상으로, 동일 환자에 서 새로 개발된 국산 구강 스캐너 $\mathrm{EzScan}^{\circledR}$ (Vatech, Hwaseong, Korea)를 사용하여 디지털 인상을 채득하 고 1 개의 금관을, 폴리비닐실록산 인상재(Examixfine Injection type, GC Corporation, Tokyo, Japan)를 사용 하여 종래형 방법으로 인상을 채득하여 2 개의 금관을 제작하였고, 이는 단일구조 지르코니아 금관으로 제작 되었다. 모든 단일구조 지르코니아 금관은 동일한 작업 방식, 설계 원리(시멘트 갭: $90 \mu \mathrm{m}$, 레이어 두께: $600 \mu$ m, edge reinforcement: $200 \mu \mathrm{m})$, 소프트웨어((Dental Designer $^{\mathrm{TM}}, 3$ Shape, Copenhagen, Denmark) 및 재료를 사용하여 같은 기공실에서 동일한 밀링 머신(imes-icore $450 \mathrm{i}^{\circledR}$, imes-icore $\mathrm{GmbH}$, Eiterfeld, Germany)으로 제 작한 다음 소결하여 완성하였다. 종래형 인상으로부터 제작된 석고모형을 기공실 스캐너인 Identica Hybrid (Medit Co, Seoul, Korea)로 스캔하여 대조군으로 설정 하고, 같은 석고모형을 새로 개발된 국산 구강 스캐너 
를 사용하여 디지털 인상을 채득하여, 획득한 두 종류의 디지털 인상을 대조군과 Geomagic software (Raindrop Geomagic, Inc, Morrisville, USA)를 사용하여 비교하 였다. 각기 다른 인상채득 방법으로 제작한 두 개의 금 관은 Replica technique으로 환자의 입안에서 수복물의 marginal fit을 평가하였고, 환자에게는 최종적으로 종래 의 인상으로부터 제작한 금관을 장착하였다.

임상시험 중 설문의 시기는 보철물제작을 위한 지대치 형성 후, 디지털인상과 종래형인상을 당일에 동시에 실시 한 직후 설문지를 대상자에게 나누어 준 다음 자기기입 방법으로 작성한 후 수거하는 방법으로 하였다. 연구의 목적에 대해 잘 이해하고 설문작성을 도와줄 수 있는 연 구위생사가 설문을 주도 하였다. 설문지의 적절성을 확 인하기 위하여 문헌고찰을 통하여 설문지를 작성한 뒤, 전문가 3 인의 검토를 바탕으로 제작되었다.

본 연구에 사용된 설문지의 구성은 일반적인 치과 진료 에 관한 내용, 종래 인상재를 이용한 인상채득법 만족도 와 국산 구강스캐너를 통한 인상채득법 만족도로 크게 3 개의 부분으로 나누어져 있으며, 두 가지의 인상채득법 의 만족도에 대한 설문은 다시 방식에 따른 전반적인 만 족도 2 문항, 구강관련만족도 5 문항, 시간 관련 만족도 2 문항으로 항목을 나누었으며, 국산 구강스캐너를 통한 인상채득법 만족도 설문에서만 스캐너 관련 만족도 4문 항을 추가하여, 스캔팁의 크기, 소음의 크기, 발열과 진동 에 관한 내용을 조사하였다.

각 방법에 대한 만족도의 척도는 리커트 5단계 척도 (Likert scale, 매우 불만족=1점, 불만족=2점, 보통=3점, 만족 $=4$ 점, 매우 만족 $=5$ 점)을 사용하여 점수화하였다. ${ }^{9}$ 일반적인 치과 진료에 관한 내용에 관한 설문에서 내원 이유, 치과치료에 대한 두려움 유무 및 원인, 디지털 인상 채득과 종래형 인상채득 경험과 구강스캐너를 통한 인상 채득법의 선호이유에 관한 항목들에 대해서는 중복응답 을 허용하였다.

\section{3. 통계분석}

연구대상자의 일반적인 특성, 내원이유, 치과치료에 대 한 두려움 유무 및 원인, 디지털 인상채득과 전통적 인상 채득에 대한 만족도의 분포는 기술통계 및 빈도분석, 다 중응답빈도분석을 이용하였고, 연구대상자의 전통적 인 상채득과 디지털 인상채득의 비교 만족도에 유의한 차 이가 있는지 보고자 paired t-test 검정을 실시하였다(Sig-
maPlot, Systat Software Inc., San Jose, USA). 최대 유의 수준 0.05 로 평균과 표준편차를 구하였다.

\section{결과}

\section{1. 연구 대상자의 일반적 특성}

인구통계학적 분석 결과 대상자의 성별은 남자가 6 명 (46.2\%), 여자가 7명(53.8\%)이고, 평균연령은 $53.92 \pm$ 10.43 살이며, 연령은 30 대가 2명(15.4\%), 40대가 3명 $(23.1 \%), 50$ 대가 4 명 $(30.8 \%), 60$ 대 이상이 4 명 $(30.8 \%)$ 으 로 나타났다. 대상치아는 상악 제 1 소구치 1 명, 상악 제 2 소구치 3 명, 상악 제 1 대구치 4 명, 하악 제 1 대구치 5 명이 었다.

\section{2. 연구 대상자의 내원 이유}

치과병원의 내원 이유는 다중응답으로 조사되었고, 총 응답 수는 25 개였다. 보철치료가 11 명 $(44.0 \%)$ 으로 가장 높은 빈도를 보였고 충치치료가 7 명 $(28.0 \%)$ 으로 대부분 을 차지하였으며, 그 외에 정기검진, 잇몸치료, 구강예방, 스케일링, 임플란트의 순으로 나타났다. 특히, 미백치료 와 틀니치료로 치과에 내원한 이유는 나타나지 않았다 (Fig. 1).

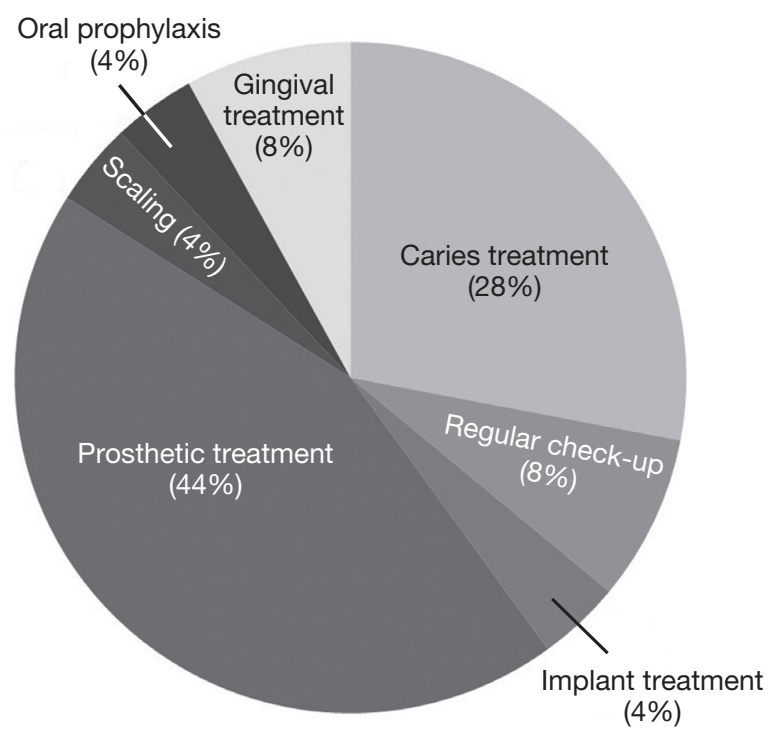

Fig. 1. The causes for visiting dental hospital. 


\section{3. 치과치료에 대한 두려움 및 원인 분석}

연구대상자들의 치과치료 시 두려움에 대한 조사에서 ‘그렇다'라고 응답한 사람이 12 명으로 전체 $92.3 \%$ 를 차 지하며 높은 비율을 보였으며 ‘그렇지 않다’라고 응답한 사람은 1 명 $(7.7 \%)$ 이었다. 두려움의 원인은 다중응답으 로 조사되었고, 총 응답 수는 30 개였다. 치과치료 중 생 기는 통증이 9 명 $(30.0 \%)$, 과거 치과치료의 통증경험이 8 명 $(26.7 \%)$ 으로 높은 비율을 차지하였으며 치과재료의 냄새가 1명(3.3\%)으로 낮은 응답을 보였다(Fig. 2). 치과 치료 중 생기는 통증은 전체응답자 중 $75 \%$ 가 응답하였 으며 과거 치과치료의 통증경험, 치과기구의 소리, 마취 주사로 인하여 치과치료에 두려움을 느끼는 것으로 나타 났다.

\section{A}

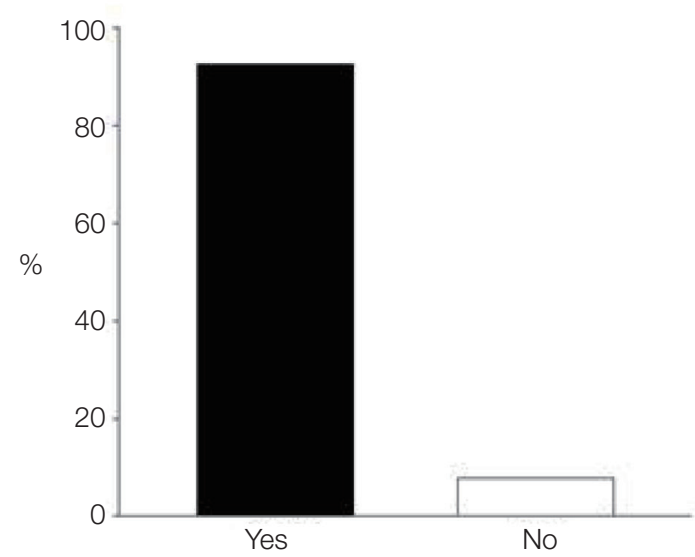

\section{4. 디지털 및 전통적 인상채득 경험의 유무}

인상재를 이용한 전통적 인상채득의 경험이 있는지에 대한 질문에, ‘그렇다'라고 응답한 경우가 8 명 $(61.5 \%)$ 이 었으며 ‘그렇지 않다’라고 응답한 경우가 5 명(38.5\%)으 로 나타났으며, 구강스캐너를 이용한 디지털 인상채득에 대한 경험이 있는지에 대해서는 '그렇다’라고 응답한 경 우가 3명 $23.1 \%)$ 이었으며 ‘그렇지 않다’라고 응답한 경 우가 10 명 $(76.9 \%)$ 으로 나타났다.

\section{5. 디지털 및 전통적 인상채득 항목에 대한 만족도 조사}

5 단계 리커트 척도를 사용한 분석 결과(Table 1), 디지

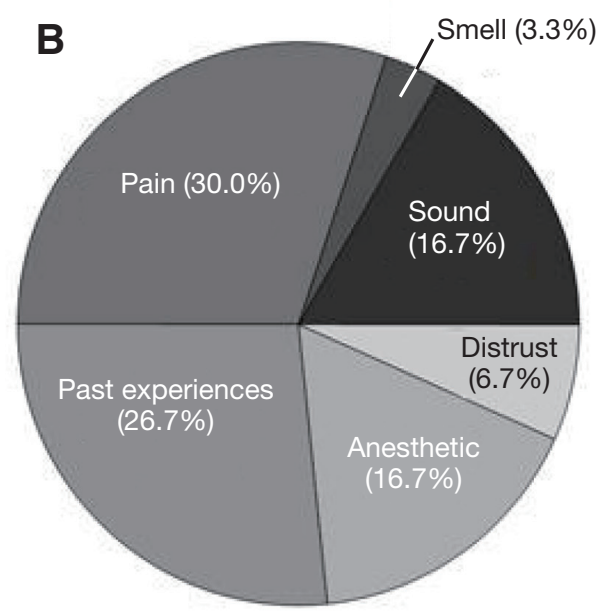

Fig. 2. (A) Participants who have dental phobia, (B) Cause of fear in dental care.

Table. 1. Patients' satisfaction for digital and conventional impression

\begin{tabular}{|c|c|c|c|c|}
\hline & Satisfaction & $\begin{array}{c}\text { Digital } \\
(\text { Mean } \pm \mathrm{SD})\end{array}$ & $\begin{array}{l}\text { Conventional } \\
(\text { Mean } \pm \mathrm{SD})\end{array}$ & $P$ \\
\hline \multirow[t]{2}{*}{ About time } & Based on participants' time perception & $3.00 \pm 1.00$ & $2.85 \pm 0.80$ & 0.436 \\
\hline & The real time required & $3.15 \pm 0.80$ & $3.23 \pm 0.73$ & 0.721 \\
\hline \multirow{2}{*}{$\begin{array}{l}\text { About the way of } \\
\text { procedure }\end{array}$} & Feeling of irritation, queasiness & $3.69 \pm 0.86$ & $3.08 \pm 0.76$ & 0.055 \\
\hline & Inconvenience & $3.15 \pm 0.99$ & $3.00 \pm 1.00$ & 0.549 \\
\hline \multirow[t]{5}{*}{ About oral region } & Discomfrot of mouth opening & $3.00 \pm 1.15$ & $2.77 \pm 0.83$ & 0.387 \\
\hline & Discomfort of TMJ & $2.92 \pm 0.76$ & $2.92 \pm 0.76$ & 1 \\
\hline & Less shortness of breath & $3.77 \pm 0.80$ & $3.15 \pm 0.95$ & $* 0.014$ \\
\hline & Odor & $3.39 \pm 1.04$ & $3.00 \pm 0.91$ & $* 0.018$ \\
\hline & Sensitivity of tooth and gingiva & $3.46 \pm 1.27$ & $3.15 \pm 0.80$ & 0.303 \\
\hline Average & & $3.28 \pm 0.31$ & $3.02 \pm 0.15$ & *0.012 \\
\hline
\end{tabular}

Likert Scale, paired t-test.

$* P<0.05$. 
털 인상채득의 경우 ‘숨쉬기’ 항목에 대한 만족도가 높았 고, ‘턱관절 불편함’에 대한 만족도가 가장 낮게 나타났 으며, 전통적 인상채득의 경우에는 '숨쉬기'에 대한 항목 이 높았고, ‘입 벌리는 정도’에 대한 항목이 가장 낮은 만 족도를 나타냈다. 특히, ‘숨쉬기'와 ‘냄새’에 대한 항목에 서는 디지털 인상채득이 전통적 인상채득에 비해 통계적 으로 유의하게 높은 환자 만족도를 나타났다 $(P<0.05)$.

전체적인 평균값으로 분석하였을 때 디지털 인상채득 의 평균 만족도는 3.28점, 전통적 인상채득은 3.02점으로 디지털 인상채득의 만족도가 통계적으로 유의하게 높게 나타났다 $(P<0.05)$.

\section{6. 인상채득법에 따른 항목별 환자 만족도 비교}

전통적 인상채득에서 방법에 따른 인상채득 시 불편 함과 이물감, 매스꺼움의 항목에서 '보통이다'가 $53.8 \%$, $46.1 \%$ 로 가장 많았으며 '불편하다'의 응답률은 각각 $15.4 \%, 23.1 \%$ 로 나타났다. 이에 대한 디지털 인상채득의 동일한 항목에서는 각각 '만족한다'는 $46.1 \%, 46.1 \%$ 로 가장 많았으며, ‘불편하다’는 각각 $15.4 \%, 7.7 \%$ 로 나타 났다. 체감상 소요시간 항목에서는 전통적 인상채득법에 서는 '보통이다'와 ‘불편하다'가 $38.5 \%$ 로 나타났으며, 디 지털 인상채득법에서는 ‘만족한다’가 $38.5 \%$ 로 가장 많았 고, ‘불편하다’는 $7.7 \%$ 로 나타났다. 또한, 소요시간 대비 만족도 항목에서는 '보통이다'의 응답률이 전통적 인상 채득법에서는 $46.2 \%$, 디지털 인상채득법에서는 $38.5 \%$ 로 가장 많았다. 특히, 구강관련 만족도 항목들 중에서 숨쉬기 어려움과 냄새의 경우 전통적 인상채득법에서는
‘보통이다’가 각각 $53.8 \%, 69.2 \%$ 로 가장 많았으며, ‘불편 하다'는 각각 $23.1 \%, 15.4 \%$ 로 나타났으며, 이에 반해 디 지털 인상채득법에서는 '만족한다'가 각각 $53.8 \%, 46.2 \%$ 로 가장 많았으며, '불편하다'는 각각 $7.7 \%, 7.7 \%$ 로 나타 났다.

디지털 인상채득 시 구강 스캐너에 대한 만족도 조사 중 스캔 팁 크기는 '보통이다'가 $53.8 \%$, 소음 크기는 '만 족한다'가 $38.4 \%$ 많았으며, ‘보통이다'는 $30.8 \%$, '매우 만족한다’는 $20 \%$ 로 나타났다. 또한, 구강 스캐너의 발열 과 진동에 대한 항목에서도 '만족한다' 이상의 응답률은 각각 $76.9 \%$ 와 $69.2 \%$ 로 나타났다. 디지털 인상채득법의 다른 사람에게 추천여부에 대한 응답으로는 '대체로 그 렇다'가 $46.2 \%$ 로 가장 많았고 그 다음으로 '매우 그렇다' 는 $23.1 \%$ 로 나타났으며, 디지털 인상채득법의 만족도 또 한 동일하게 '대체로 그렇다'가 $38.4 \%$ 로 가장 많았고 그 다음으로 ‘매우 그렇다’는 23.1\%로 나타났다.

\section{7. 추천 인상 채득법 및 보철 진료 관련 적극 사용 여부}

추천하고 싶은 인상채득 방법으로 전통적 인상채득보 다 디지털 인상채득이 높게 나타났으며(Fig. 3), 향후 보 철 진료 시 적극적 사용 여부는 ‘그렇다’가 $92.3 \%$ 가 매우 높게 나타났으며, 그 원인으로는 '종래 인상채득법 보다 불편함이 덜하다'가 $50 \%$, ‘체감 상 소요시간이 짧은 것 같다'와 ‘3D 구강스캐너에 대한 신뢰'가 각각 $16.7 \%$, 교 차 감염에 대한 불안감 해소가 $8.3 \%$ 순으로 응답을 하였 다(Fig. 4).

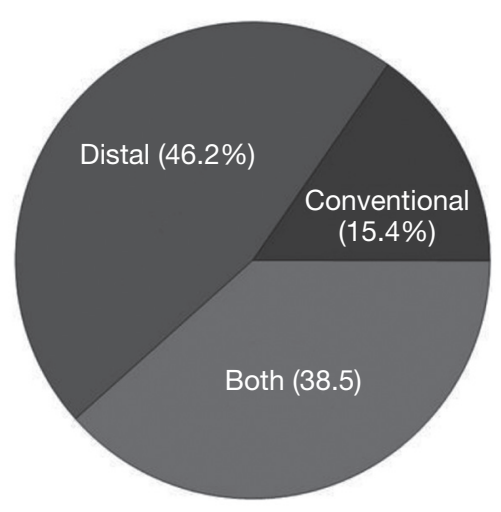

Fig. 3. The type of impression technique what participants want to recommend.
A
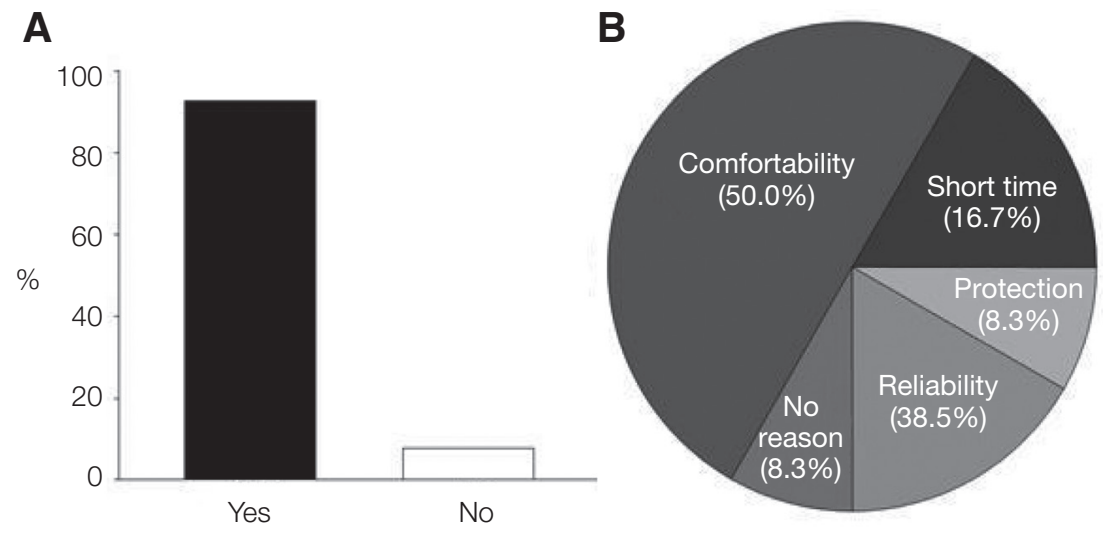

Fig. 4. (A) An answer to the question: "Will you take the digital impression technique for future prosthetic treatment?" (B) Reasons for the participants to prefer the digital impression technique. 


\section{고찰}

본 연구는 서울대학교 치과병원에서 시행된 임상연구 “새로 개발된 국산 구강 스캐너와 간접법 디지털 인상의 정확도 및 $\mathrm{CAD} / \mathrm{CAM}$ 으로 제작된 단일구조 지르코니아 단일금관의 적합도 평가 임상연구”에 참여한 13 명의 임 상시험자를 대상으로한 설문내용을 분석한 것이다.

이 연구는 두 가지 인상채득의 시기가 2 - 3주의 간격 을 가지고 설문을 행한 Yuzbasioglu 등 ${ }^{10}$ 의 연구와는 다 르게 치아삭제 후 같은 날에 두 가지 인상채득의 방법을 연속으로 시행하고, 즉시 설문지를 작성하게 함으로써 대상자의 느낌을 정확히 반영하려고 하였고, 두 가지의 인상채득방법에 대한 효과와 선호도를 잘 조절된 임상시 험을 통하여 진행하였다.

전체적인 평균값으로 분석하였을 때 디지털 인상채득 의 평균 만족도는 3.28점, 전통적 인상채득은 3.02점으로 디지털 인상채득의 만족도가 통계적으로 유의하게 높게 나타났으므로 $(P<0.05)$ 귀무가설은 기각되었다.

Lee 등 ${ }^{11}$ 의 연구에 따르면 숙련된 임상가에 비해 치과 대한 학생들이 종래형 인상법을 더 어렵게 여긴다고 하 였고, 임상경험이 적은 치과대학 학생들은 효율적인 인 상채득방법으로 디지털인상을 선호하였으나, 기존 임상 가들은 두 가지 인상법에 대한 선호도의 차이가 없다고 했다. 종래형인상과 디지털 인상의 시간효율성과 술자의 선호도를 조사한 Joda 등 ${ }^{12}$ 의 유사한 연구에서도 디지털 인상이 시간 효율성면에서 우수하며, 치과대학학생 및 기 존 임상가들 모두 디지털 인상을 선호한다고 하였다.

위에 언급한 술자 중심의 연구와 달리 이를 환자의 관 점에서의 두 가지 인상방법에 대한 느낌과 선호도를 조 사한 여러 연구에서도 구강스캐너를 이용한 디지털인상 법이 종래형인상법에 비하여 시간이 절감되며 환자들이 더 선호하는 방법이라고 발표하였다. ${ }^{10,13}$ 제 1 소구치 단일 임플란트 치료에서 두 가지 인상의 작업시간과 환자선호 도를 조사한 Schepke 등 ${ }^{13}$ 의 연구에 따르면 디지털 인상 채득 작업시간이 6 분 39 초로 종래형인상의 12 분 13 초에 비하여 절반정도 적게 소요되었고, 환자들도 디지털 인상 이 덜 불편하고, 인상시 숨쉬기가 더 편안했고, 반복되는 인상채득에 대한 공포가 적었으며 인상채득 과정 중에 난감함이 적어서, 선호한다고 하였다. 그러나 Benic 등 ${ }^{14}$ 의 연구에서는 종래형 인상법이 시간효율성면에서 디지 털 인상법보다 우수하며, 환자의 편안함은 두 가지인상 법에서 차이가 없었다고 했고, Wismeijer 등 $^{15}$ 의 연구에
서도 환자의 전반적인 선호도는 디지털 인상의 선호도가 높게 나타났고, 특히 미각효과, 냄새, 구토반사에서 구강 스캐너를 사용한 디지털인상이 유리하게 작용하였으나, 환자들은 구강스캔 지속시간이 아날로그 인상 접근방식 보다 더 길게 인식하였다.

우리의 연구는 전반적인 리커트 척도 평균값을 분석하 였을 때 디지털인상의 평균만족도가 통계학적으로 유의 하게 높게 나타났다 $(P<0.05)$. 특히 디지털 인상에서 ‘숨 쉬기'와 '냄새'에 대한 항목에서 높은 환자 만족도가 나 타났다(Table 1). 종래형 인상법에서는 인상채득 시 입 벌 리는 정도와 턱관절의 불편함 그리고 인상채득 소요시간 에서 비교적 낮은 만족도를 보이는 것으로 나타났다. 이 에 반해 국산 구강스캐너를 통한 디지털인상법에서는 전 반적으로 보통이상의 만족도를 보였으며 턱관절의 불편 함 부분에서 약간 낮은 만족도를 나타낸다는 것을 알 수 있었고, 인상채득 시 이물감, 매스꺼움 정도에 대해서 전 체 설문 내용 중 가장 높은 만족도를 나타내어 구강스캐 너를 사용한 인상채득이 종래형에서 환자가 느끼는 인상 채득에 대한 공포와 난감함을 없앨 수 있는 가장 큰 장점 으로 판단되었다. 국산 구강스캐너 관련 만족도 분석에 서 스캐너 팁의 크기에 대한 낮은 만족도를 보였는데 이 는 스캐너를 개발하는 회사에서 참고하여 스캐너 팁의 소형화에 힘을 기울여야 할 것으로 사료 된다.

이 연구의 한계는 직접 환자를 대상으로 치아를 삭제 하고 보철물을 제작하는 임상시험으로 진행되었기 때문 에 임상시험에서 요구하는 최소한의 통계적 유의성을 가 지는 시험대상자 수로 설문이 진행되어 상대적으로 적은 샘플 수로 연구가 진행되었으며, 여러 시험자가 시행 시 생기는 에러를 없애기 위해 한 명의 치과의사가 치아삭제 와 모든 인상과정을 포함하는 전 과정이 진행되었다. 때 문에 디지털 인상에 대한 술자 및 보조인력의 선호나 효 과에 대한 내용을 포함할 수 없었다는 한계점이 있었으 며, 디지털 인상이 가지고 있는 장점인 인상 후 모델을 만 드는 복잡한 여러 단계가 생략되고 구강스캔 후 즉시 가 상모델이 제작되고 석고모델 없이 digital work flow로 기 공과정이 진행되는 것에 대한 내용을 설문에 반영할 수 없었던 한계가 있었다.

\section{결론}

전반적인 설문분석결과 종래형 인상채득법 보다 개발 중인 국산 스캐너를 통한 디지털 인상에 대한 선호도가 
높다는 것을 확인할 수 있었으며, 디지털 인상채득법의 다른 사람에게 추천여부와 향후 보철 진료 시 적극적인 사용여부에도 ‘그렇다’가 $92.3 \%$ 로 매우 높게 나타났다. 이는 향후 구강스캐너의 보완을 통해 디지털 인상의 보 편화의 높은 가능성을 보여준다. 추가적으로 본 설문조 사를 통하여 스캐너 팁의 크기 조절을 통해 환자만족도 를 높이기 위한 개선사항을 도출할 수 있었다는 점에서 큰 의의를 둘 수 있을 것이다.

\section{Acknowledgements}

This study was supported by a grant of Ministry for Trade, Industry, and Energy, Republic of Korea (10048888).

\section{ORCID}

Eunbee Yang https://orcid.org/0000-0002-1241-306X Bongju Kim https://orcid.org/0000-0001-7309-5977

Jun Jae Lee https://orcid.org/0000-0002-5496-0168

Seung-Pyo Lee https://orcid.org/0000-0002-0103-6705

Young-Jun Lim https://orcid.org/0000-0003-2504-9671

\section{References}

1. Morey EF. Dimensional accuracy of small gold alloy castings. Part 1. A brief history and the behaviour of inlay waxes. Aust Dent J 1991;36:302-9.

2. Barbosa GA, Simamoto Júnior PC, Fernandes Neto AJ, de Mattos Mda G, Neves FD. Prosthetic laboratory influence on the vertical misfit at the implant/ UCLA abutment interface. Braz Dent J 2007;18: $139-43$.

3. Beuer F, Schweiger J, Edelhoff D. Digital dentistry: an overview of recent developments for CAD/ CAM generated restorations. Br Dent J 2008;204: 505-11.

4. Davidowitz G, Kotick PG. The use of CAD/CAM in dentistry. Dent Clin North Am 2011;55:559-70.

5. Prudente MS, Davi LR, Nabbout KO, Prado CJ, Pereira LM, Zancopé K, Neves FD. Influence of scanner, powder application, and adjustments on CAD-CAM crown misfit. J Prosthet Dent 2018; 119:377-83.
6. Takeuchi Y, Koizumi H, Furuchi M, Sato Y, Ohkubo C, Matsumura H. Use of digital impression systems with intraoral scanners for fabricating restorations and fixed dental prostheses. J Oral Sci 2018;60:1-7.

7. Seelbach P, Brueckel C, Wöstmann B. Accuracy of digital and conventional impression techniques and workflow. Clin Oral Investig 2013;17:1759-64.

8. Zhang F, Suh KJ, Lee KM. Validity of Intraoral Scans Compared with Plaster Models: An In-Vivo Comparison of Dental Measurements and 3D Surface Analysis. PLoS One 2016;11:e0157713.

9. Kim KM. Likert scale. Korean J Fam Med 2011;32: 1-2.

10. Yuzbasioglu E, Kurt H, Turunc R, Bilir H. Comparison of digital and conventional impression techniques: evaluation of patients' perception, treatment comfort, effectiveness and clinical outcomes. BMC Oral Health 2014;14:10.

11. Lee SJ, Macarthur RX 4th, Gallucci GO. An evaluation of student and clinician perception of digital and conventional implant impressions. J Prosthet Dent 2013;110:420-3.

12. Joda T, Lenherr P, Dedem P, Kovaltschuk I, Bragger U, Zitzmann NU. Time efficiency, difficulty, and operator's preference comparing digital and conventional implant impressions: a randomized controlled trial. Clin Oral Implants Res 2017;28:131823.

13. Schepke U, Meijer HJ, Kerdijk W, Cune MS. Digital versus analog complete-arch impressions for singleunit premolar implant crowns: Operating time and patient preference. J Prosthet Dent 2015;114:403-6.

14. Benic GI, Mühlemann S, Fehmer V, Hämmerle $\mathrm{CH}$, Sailer I. Randomized controlled within-subject evaluation of digital and conventional workflows for the fabrication of lithium disilicate single crowns. Part I: digital versus conventional unilateral impressions. J Prosthet Dent 2016;116:777-82.

15. Wismeijer D, Mans R, van Genuchten M, Reijers HA. Patients' preferences when comparing analogue implant impressions using a polyether impression material versus digital impressions (Intraoral Scan) of dental implants. Clin Oral Implants Res 2014;25:1113-8. 
안녕하십니까?

서울대학교 치과병원 임상연구과제로 〈새로 개발된 국산 구강스캐너와 간접법 디지털 인상의 정확도 및 $\mathrm{CAD} / \mathrm{CAM}$ 으로 제작된 단일구 조 지르코니아 단일금관의 적합도 평가에 관한 임상연구>를 수행하고 있습니다.

본 연구의 일환으로 국내개발 구강 스캐너를 이용한 직접 인상채득법과 인상재를 이용한 인상채득법에 대한 비교 설문을 실시하오니 바 쁘시더라도 성실히 응답하여 주시기 바랍니다. 감사합니다.

$\odot$ 연구관련 질문사항 또는 이해할 수 없는 단어나 의학 용어가 있는 경우에는 어떤 것이든 연구담당자 또는 연구책임자에게 자세한 설명을 요청하십시오.

다음은 환자분 개인에 관련된 사항입니다.

- 귀하의 연령은?

(1) 20 대 이하 (2) 30 대 (3) 40대 (4) 50 대 (5) 60 대 이상

- 귀하의 성별은?

(1) 남 (2) 여

- 귀하의 직업은?

(1) 학생 (2) 전문직 (3) 자영업 (4) 농업, 임업, 어업

(5) 기술직, 판매 서비스직 (6) 사무직 (7) 공무원 (8) 군인

(9) 교사 (11) 종교인 (11) 예술인 (12) 주부 (13) 무직 (14) 기타( )

- 귀하의 최종학력은?

(1) 고등학교 졸업 이하 (2) 대학교 재학 (3) 대학교 졸업

(4) 대학원 재학 (5) 대학원 졸업

일반적인 치과 진료에 관한 질문입니다.

1. 귀하가 치과에 내원하신 이유는 무엇입니까? (중복선택 가능) (1) 충치치료 (2) 잇몸 치료 (3) 구강예방 치료 (4) 스케일링 치료

(5) 미백 치료 (6) 보철 치료 (7) 임플란트 치료 (8) 틀니 치료

(9) 정기적인 구강검진

2. 귀하는 치과치료에 대한 두려움이 있습니까?

(1) 그렇다(3번으로 이동) (2) 그렇지 않다(4번으로 이동)

3. 치과치료가 두려운 이유는 무엇입니까? (중복선택 가능)

(1) 치과기구의 소리 (2) 치과재료의 냄새

(3) 치과치료 중 생기는 통증 (4) 과거 치과치료의 통증경험

(5) 마취주사 (6) 치과의사에 대한 불신 (7) 기타( )

4. 인상재를 이용한 인상채득(간접법)의 경험이 있습니까?

(1) 그렇다 (2) 그렇지 않다
5. 구강스캐너를 이용한 인상채득(직접법)의 경험이 있습니까? (1) 그렇다 (2) 그렇지 않다

6. 본 임상연구에 참여하신 경험을 바탕으로 추천하고 싶은 인상채득법은 무엇입니까?

(1) 인상재를 이용한 인상채득(간접법)

(2) 구강스캐너를 이용한 인상채득(직접법)

(3) 둘 다

7. 추후 보철관련 진료와 관련하여 구강스캐너를 통한 인상채 득법을 사용할 의사가 있습니까?

(1) 전혀 사용할 의사가 없다

(2) 적극 사용할 의사가 있다(8번으로 이동)

8. 구강스캐너를 통한 인상채득법을 선호하는 이유는?

(1) 체감상 소요시간이 짧은 것 같다

(2) 종래 인상채득법보다 불편함(냄새, 구토감 등)이 덜 하다

(3) 교차감염에 대한 불안감 해소

(4) 3D 구강스캐너에 대한 신뢰

(5) 특별한 이유가 없다

9. 구강스캐너를 통한 인상채득법을 다른사람에게 추천하시겠 습니까?

(1) 전혀 그렇지 않다 (2) 대체로 그렇지 않다 (3) 보통이다

(4) 대체로 그렇다 (5) 매우 그렇다

10. 구강스캐너를 통한 인상채득법에 만족하십니까?

(1) 전혀 그렇지 않다 (2) 대체로 그렇지 않다 (3) 보통이다

(4) 대체로 그렇다 (5) 매우 그렇다 
1. 종래 인상재를 이용한 인상채득법 만족도 설문지

\begin{tabular}{|c|c|c|c|c|c|c|}
\hline \multirow{2}{*}{ 항목 } & \multirow{2}{*}{ Parameter } & \multicolumn{5}{|c|}{ Scale } \\
\hline & & 매우불편 & 불편 & 보통 & 만족 & 매우만족 \\
\hline \multirow{2}{*}{ 방식에 따른 전반적인 만족도 } & 인상채득 시 불편함의 정도 & 1 & 2 & 3 & 4 & 5 \\
\hline & 인상채득 시이물감, 매스꺼움의 정도 & 1 & 2 & 3 & 4 & 5 \\
\hline \multirow{5}{*}{ 구강관련 만족도 } & 인상채득시입 벌리는 정도 & 1 & 2 & 3 & 4 & 5 \\
\hline & 인상채득 시턱관절의 불편함 정도 & 1 & 2 & 3 & 4 & 5 \\
\hline & 인상채득 시숨쉬기의 어려움 정도 & 1 & 2 & 3 & 4 & 5 \\
\hline & 인상채득 시발생하는 냄새의 정도 & 1 & 2 & 3 & 4 & 5 \\
\hline & 인상채득 시치아, 잇몸 관련하여 예민함 정도 & 1 & 2 & 3 & 4 & 5 \\
\hline \multirow{2}{*}{ 시간 관련 만족도 } & 체감상 소요시간 정도 & 1 & 2 & 3 & 4 & 5 \\
\hline & 소요시간 대비만족도 & 1 & 2 & 3 & 4 & 5 \\
\hline
\end{tabular}

\section{2. 국산 구강스캐너를 통한 인상채득법 만족도 설문지}

\begin{tabular}{|c|c|c|c|c|c|c|}
\hline \multirow{2}{*}{ 항목 } & \multirow{2}{*}{ Parameter } & \multicolumn{5}{|c|}{ Scale } \\
\hline & & 매우불편 & 불편 & 보통 & 만족 & 매우만족 \\
\hline \multirow{2}{*}{ 방식에 따른 전반적인 만족도 } & 인상채득(구강기록) 시불편함의정도 & 1 & 2 & 3 & 4 & 5 \\
\hline & 인상채득 시이물감, 매스꺼움의정도 & 1 & 2 & 3 & 4 & 5 \\
\hline \multirow{5}{*}{ 구강관련 만족도 } & 인상채득 시입 벌리는 정도 & 1 & 2 & 3 & 4 & 5 \\
\hline & 인상채득 시턱관절의불편함 정도 & 1 & 2 & 3 & 4 & 5 \\
\hline & 인상채득 시숨쉬기의 어려움 정도 & 1 & 2 & 3 & 4 & 5 \\
\hline & 인상채득 시발생하는 냄새의 정도 & 1 & 2 & 3 & 4 & 5 \\
\hline & 인상채득 시치아, 잇몸 관련하여 예민함 정도 & 1 & 2 & 3 & 4 & 5 \\
\hline \multirow{2}{*}{ 시간 관련 만족도 } & 체감상 소요시간 정도 & 1 & 2 & 3 & 4 & 5 \\
\hline & 소요시간 대비만족도 & 1 & 2 & 3 & 4 & 5 \\
\hline \multirow{4}{*}{ 스캐너 관련 만족도 } & 스캔팁(부리)의크기의 정도 & 1 & 2 & 3 & 4 & 5 \\
\hline & 소음의크기 정도(1: 아주 많음, $3:$ 보통, $5:$ 전혀 없음) & 1 & 2 & 3 & 4 & 5 \\
\hline & 발열의 정도(1: 아주 많음, 3: 보통, 5: 전혀 없음) & 1 & 2 & 3 & 4 & 5 \\
\hline & 진동의 정도(1: 아주 많음, $3:$ 보통, 5: 전혀 없음) & 1 & 2 & 3 & 4 & 5 \\
\hline
\end{tabular}

설문에 응해 주셔서 대단히 감사합니다. 


\section{디지털 인상법과 종래인상법을 동시에 경험한 임상시험자를 대상으로 한 설문지분석}

\section{양은비 ${ }^{1}$, 김봉주 ${ }^{2}$, 이준재 ${ }^{1}$, 이승표 ${ }^{3}$, 임영준 ${ }^{1 *}$}

${ }^{1}$ 서울대학교 치의학대학원 치과보철학교실

${ }^{2}$ 서울대학교 치과병원 치의생명과학연구원

${ }^{3}$ 서울대학교 치의학대학원 구강해부학교실

목적: 이 연구의 목적은 종래형 인상채득 방법과 디지털 인상채득 방법에 대한 환자들의 느낌, 만족도와 선호도를 설문 조사를 통해 비교분석하는 것이다.

연구 재료 및 방법: 이 연구에 참여한 13 명의 임상시험자(남자 6 명, 여자 7명)는 종래형 인상채득 방법과 디지털 인상채득 방법을 동일에 경험하였다. 종래형 인상채득방법은 폴리비닐실록산(PVS) 인상재를 사용하였고, 디지털 인상채득은 새 로 개발된 구강스캐너를 사용하였다. 두 종류의 인상채득을 시행한 직후 바로 설문조사를 진행하였고, 설문조사지는 다 음의 세 개의 범주로 구성되었다; 1) 일반적인 치과 진료에 관해 2) 종래형 인상채득방법에 대한 만족도 3) 디지털 인상채 득 방법에 대한 만족도. 만족도에 대한 측정은 Likert 척도를 사용하여 평가되었다. 설문조사 응답 중 분포에 관한 것은 백분율을 사용하였고, 비교 만족도에 유의성에 대한 통계분석은 paired t-test 검정을 사용하였으며 통계적 유의수준은 $P$ $<0.05$ 로 하였다.

결과: 두 가지 인상채득 방법에 대한 전반적인 만족도에서 유의미한 차이가 있었다 $(P<0.05)$. 디지털 인상채득방식이 숨 쉬기, 냄새에 대한 항목에서 종래의 인상채득방법에 비해 높은 만족도를 보였다. 다만 구강 스캐너를 사용했을 때 스캐 너의 팁 사이즈가 크고 입을 오래 벌리고 있어야 하는 문제로 인해 TMJ에 불편감을 야기했다.

결론: 구강스캐너를 사용하는 디지털 인상채득 방법이 종래의 인상채득방법에 비하여 더 선호되는 것을 확인하였다. 대 부분의 조사에서 참가자들이 디지털 인상채득방법을 타인에게 추천할 의향이 있으며, 다음 보철 치료 시에도 디지털 인 상채득 방법을 선택할 것이라고 했다.

(구강회복응용과학지 2018;34(4):270-9)

주요어: 설문조사; 종래형인상법; 디지털인상법; 구강스캐너; 임상시험

*교신저자: 임영준

(03080)서울시 종로구 대학로 101 서울대학교 치의학대학원 치과보철학교실

Tel: 02-2072-2940 | Fax: 02-2072-3860 | E-mail: limdds@snu.ac. kr

|접수일: 2018년 8월 17일 | 수정일: 2018년 9월 12일 | 채택일: 2018년 10월 2일 